\title{
US budget does well by big science in 1989 proposal to Congress
}

Washington

President Reagan's \$1.094 million million 1989 budget, released last week, does well by big science. The Superconducting Super Collider (SSC), the space station and the Strategic Defense Initiative (SDI) are all in line for healthy funding. But Congress may not be willing to join the White House in committing the United States to large projects for which the major costs will be felt only after President Reagan has left office. Even in less contentious areas, the budget that ultimately emerges from Congress may be quite different from the blueprint the White House has proposed.

The proposed budget represents a compromise between philosophical ideals and political realities. Restrained by an agreement worked out with Congress last November to reduce the federal deficit, the president's swansong budget is more muted in its support for ideologically contentious programmes.

The massive military buildup begun by the Reagan administration slows considerably, although prized projects such as SDI retain strong support. Much of the rationale for federal spending on science and technology remains tied to strengthening economic competitiveness. The

1989 budget request (millions of dollars)

\begin{tabular}{|c|c|c|c|}
\hline Agency & $1989 \mathrm{H}$ & Request & $\begin{array}{l}\% \text { Change } \\
\text { from } 1988\end{array}$ \\
\hline \multirow{3}{*}{ DoD } & & 299,529 & 2.8 \\
\hline & Research & 38,800 & 2.0 \\
\hline & SDI & $4,950^{*}$ & 39.8 \\
\hline \multirow[t]{5}{*}{ NSF } & & 2,050 & 19.4 \\
\hline & Research & 1,603 & 10.3 \\
\hline & Education & 156 & 12.2 \\
\hline & Antarctic pgms & 141 & 12.8 \\
\hline & S \& T centres & 150 & N/A \\
\hline \multicolumn{2}{|c|}{ NASA } & 11,488 & 27.3 \\
\hline & Space station & 967 & 46.7 \\
\hline & Space science & 1,860 & 18.0 \\
\hline \multirow[t]{5}{*}{ DoE } & & 16,080 & 13.9 \\
\hline & Research & 1,713 & 25.3 \\
\hline & SSC & 363 & $1,352.0$ \\
\hline & Human genome & 19 & 76.6 \\
\hline & Superconductivity & 95 & 41.2 \\
\hline \multirow{5}{*}{ HHS } & & 464,800 & 8.6 \\
\hline & $\mathrm{NIH}$ & 6,535 & 5.4 \\
\hline & CDC & 523 & 1.4 \\
\hline & AIDS & 1,300 & 36.7 \\
\hline & Human genome & 27 & 58.8 \\
\hline \multicolumn{2}{|c|}{ Interior } & 5,950 & -9.6 \\
\hline & USGS & 425 & -5.1 \\
\hline \multicolumn{2}{|c|}{ Commerce } & 2,423 & -0.6 \\
\hline & NOAA & 1,121 & -2.9 \\
\hline \multicolumn{2}{|l|}{ EPA } & 3,129 & -24.1 \\
\hline
\end{tabular}

* Includes $\$ 400$ million from DoE. budget calls for spending on non-military basic research to rise some 6 per cent to $\$ 10,300$ million for 1989 .

National Aeronautics and Space

Administration (NASA)

Space activities receive a significant influx of new money from the president's budget. The increase is related to the planned resumption of shuttle flights, now scheduled for this summer, the first construction phase for the international permanently manned space station.

Only one new space science mission is included in NASA's budget request; the Advanced X-Ray Facility, one of the socalled "great observatories" planned to accompany the Hubble Space Telescope and the planned Gamma-Ray Observatory. The comet rendezvous, asteroid fly-by mission (CRAF), is passed over, although missions to Mars (Mars-Observer), Venus (Magellan) and Jupiter (Galileo) continue to receive support. The administration is seeking $\$ 100$ million for the Pathfinder Program, a new advanced technology initiative.

\section{National Science Foundation (NSF)}

The plans announced last year to double the NSF budget over the next 5 years got off to a shaky start in 1988, with Congress appropriating funds amounting to only a 6 per cent increase over 1987. But director Erich Bloch says the administration remains committed to its 5-year plan, and the new budget request reflects that. Support for the proposed multidisciplinary Science and Technology Centers appears as a separate line item for the first time. The \$150-million request would cover the full 5-year cost of 12-15 centres. NSF hopes that such 'up-front' funding would protect the centres from future budgetary fluctuations.

The administration is also seeking big increases for NSF supercomputing activities. A 53-per-cent increase in money for networking and communications research and infrastructure will permit work to continue on NSFNET, NSF's high-speed computer network.

\section{Health and Human Services}

After the administration's plan last year to cut the budget of the National Institutes of Health (NIH) by $\$ 750$ million was thwarted by Congress, its request this year rises 5.4 per cent. Most of this increase is requested for research project grants.

The number of new grants $(5,611)$ is fewer than in 1988 but is enough to bring the total to a record 20,600 . The amount available for each grant would increase by about 3 per cent for new grants and just under 5 per cent for existing ones.

Intramural research is treated less generously, budgeted with barely enough to

\section{Polish physicist} gets a job at last

\section{London}

Professor Andrzej Jurewicz, one of the pro-Solidarity physicists from Warsaw's former Institute of Nuclear Research, who lost his job when the institute was reorganized into three new establishments at the end of 1982, has at last found work after almost five years. The reorganization of the institute made it possible to purge it of political "undesirables" without contravening the labour laws on academic tenure. Jurewicz's new post, which carries the rank of docent (associate professor) is at the Space Research Centre in Warsaw.

Commenting on Jurewicz's new appointment, W Okopach (In the trenches), the underground Solidarity bulletin of the Warsaw nuclear research establishments (No. 93, 20 January 1988), said: "No one ever told him, right up to the end, why he had been thrown out. We believe that a certain role in the resolution of this kafkaesque situation was played by an article in Nature (No. 6121), which created a considerable stir".

Vera Rich

cover inflation (up 3.7 per cent on 1988). Support for the human genome project has been increased from $\$ 17$ million to $\$ 27$ million, with the emphasis on identifying chromosomal markers close to genes associated with known genetic disorders.

Research into AIDS retains its high priority and is now dealt with as a separate budget item. Of the $\$ 1,300$ million requested, $\$ 400$ million is to be spent on education. NIH would receive $\$ 588$ million, $\$ 120$ million more than they will spend on AIDS research in 1988. The Centers for Disease Control (CDC), responsible for a nationwide public information campaign, would receive $\$ 401$ million compared with $\$ 301$ million in 1988. Although CDC's AIDS activities will increase, their other programmes do not keep pace with inflation in the proposed budget.

Department of Energy

Of the $\$ 16,080$ million requested by the Department of Energy (DoE), slightly less than half goes to defence activities. But Under Secretary Joseph Salgado, announcing the numbers, emphasized that the proportion of DoE spending devoted to defence has fallen from the 68 per cent spent two years ago, with a number of big civil science projects, notably the SSC, as the beneficiaries.

The $\$ 363$ million requested to begin construction of SSC is essentially the same amount as was requested and turned down by Congress last year, when only $\$ 25$ million for continuing research and development was made available. And although DoE also hopes to start building a 6-GeV synchrotron light source at 
Argonne National Laboratory, the 'big science' community does not escape scotfree: about $\$ 60$ million has been deleted from the basic energy science research budget, which includes much support of high-energy physics experimentation.

Research into superconductivity, covering traditional 'low-temperature' materials as well as the new superconductors, benefits to the tune of $\$ 95$ million, and a project to collaborate with industry on the exploitation of hightemperature superconductors is planned for Los Alamos National Laboratory.

A sum of $\$ 19$ million has been set aside for work on the human genome project, in collaboration with NIH.

\section{Department of Defense}

SDI retains high priority with a 40 per cent increase requested, well above the 2.8 per cent rise scheduled for total defence spending, and the 2.0 per cent for nonSDI research programmes. But the projected $\$ 4,950$-million expenditure is still almost $\$ 2,000$ million below that planned by the administration a year ago and will require cuts in some SDI projects.

The trend towards research on high velocity interceptor rockets and other kinetic-energy weapons at the expense of research on exotic particle-beam weapons is likely to intensify as the administration looks for early results.

The fact that more tests will be necessary is sure to bring the administration back into conflict with Congress over the interpretation of the Anti-Ballistic Missile Treaty.

In the non-SDI research programme, the 'Orient Express' National Aerospace Plane is budgeted for a large increase in a joint project with NASA. Another collaboration with NASA is the Advanced Launch System, an expendable rocket for heavy payloads.

A set of basic research programmes in electronics is also emphasized, including a very-high-speed integrated circuit project and support for Sematech, the private microchip research consortium.

Other Agencies

The administration request for the US Geological Survey (USGS) reflects reductions for "numerous lower priority program activities". The areas being cut back include regional aquifer analysis, nuclear waste and coal hydrology and work on coastal erosion. Extra money is requested for advanced cartoraphic systems.

The National Oceanographic and Atmospheric Administration continues its fall from financial favour in the White House budget. Marooned by bureaucratic structure in the Department of Commerce, it will be cut in all research and operational areas, except environmental satellite date, which receive an increase mostly for the purchase of replacement weather satellites.

\section{Army renews controversial plans for biological warfare laboratory}

Boston

THE debate over the US Army's plans to build a controversial high-containment facility to study biological warfare agents was rekindled with the recent release of a draft environmental impact statement attesting to the safety of the venture.

The Army's lengthy report concludes that the facility, designed for aerosol testing and experimentation with deadly and highly infectious biological warfare agents, "would have no reasonably fore-

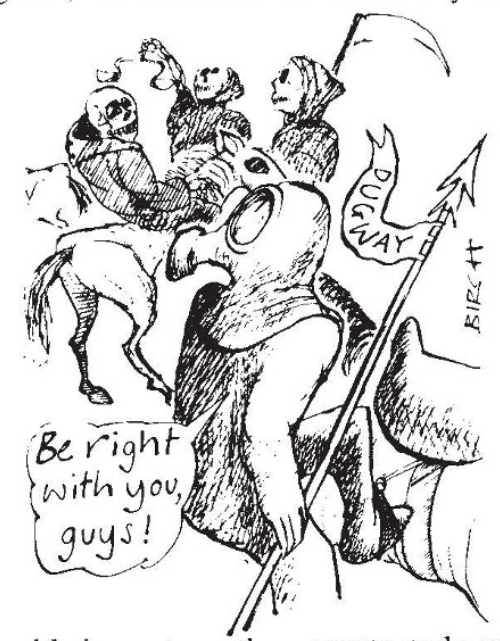

seeable impacts on the unprotected populace or the environment". The multimillion-dollar facility is at the Army's Dugway Proving Ground in Utah.

The Army's impact statement does acknowledge a potential hazard from "accidental occupational exposure" if an infected worker were to leave the facility, but claims that sufficient steps have been taken to avoid such a prospect in the design of the facility and in a programme to immunize workers against the diseases they will study. A two-month comment period now follows the issuing of the draft report, after which a final impact statement will be released. But critics of the Dugway facility are already complaining.

The proposed "maximum-containment" facility at Dugway has been a cause of controversy since its conception. The Army's current environmental impact statement emerged only after a court ruling in 1985 in response to a successful lawsuit brought by the Foundation on Economic Trends, led by Jeremy Rifkin.

Rifkin calls the latest report "grossly inadequate", claiming that the reviewers failed to consider seriously the possibilities of sabotage and terrorism, the proposed use of non-lethal simulants instead of actual pathogens, or the possibility of siting the facility elsewhere. Rifkin threatens to sue again unless these and other criticisms are dealt with in the final report.

Barbara Rosenberg, a research scientist at the Sloan Kettering Institute in New York and also an outspoken critic of the facility, and other scientists, including Nobel laureate David Baltimore, have argued against the construction of the facility at Dugway.

Very few known warfare agents require the highest biosafety level (BL-4) containment that the Army proposes for the Dugway facility. In fact, the Army claims that only research requiring the lower BL-3 rating will be conducted at Dugway, but it wants the capability to conduct the more dangerous research.

Seth Shulman
NIH conclude misconduct investigation

\section{Washington}

AN investigation by the National Institutes of Health (NIH) has concluded that there were "serious misrepresentations" in two published papers on the $\mathrm{T}$-cell-activating substance interleukin-4A (IL-4A), and has recommended that the senior author of the paper, Claudio Milanese, be excluded from receiving any further money from NIH.

Milanese was a postdoctoral fellow in the laboratory of Ellis Reinherz at the DanaFarber Cancer Institute in Boston. In October 1986, Reinherz became aware that some of the data provided by Milanese had been fabricated (see Nature 324, 193; 1986). He contacted NIH about the irregularities, and retracted two papers containing the fradulent data (Science 231, 1118; 1986 by Milanese, Neil E. Richardson and Reinherz and $J$. exp. Med. 163, 1583; 1986 by Milanese, Robert E. Siciliano, Reinhold
Schmidt, Jerome Ritz, Richardson and Reinherz). Two other papers in the press were withdrawn. An investigation by Dana-Farber and Harvard Medical School concluded that, in addition to inventing data, Milanese had supplied fraudulent materials to others, and was guilty of "tidying" data to achieve better-looking results.

NIH have now accepted the conclusions of the Dana-Farber investigation. Although the main blame is laid on Milanese, the investigation noted that Reinherz's extensive research commitments "raised troubling questions about the supervision of junior staff in the laboratory." Harvard Medical School and Dana-Farber have agreed to form a committee to monitor Reinherz's laboratories. NIH praise Reinherz and Dana-Farber for investigating this incident and promptly informing the scientific community. 